\title{
Migraine, ataxia and epilepsy: a challenging spectrum of genetically determined calcium channelopathies
}

\author{
GM Terwindt ${ }^{1}$, RA O phoff ${ }^{1,2}$, Joost Haan ${ }^{1,3}$, LA Sandkuijl ${ }^{2,4}$, R R Frants ${ }^{2}$ and \\ M D Ferrari for the D utch M igraine G enetics R esearch G roup* \\ ${ }^{1}$ D epartment of N eurology and ${ }^{2}$ M G C D epartment of H uman G enetics, L eiden U niversity M edical Centre, L eiden \\ ${ }^{3} \mathrm{D}$ epartment of N eurology, Rijnland Hospital, L eiderdorp \\ ${ }^{4} \mathrm{M}$ G C D epartment of Clinical G enetics, E rasmus U niversity R otterdam, The N etherlands
}

\begin{abstract}
Clinical and genetic heterogeneity as well as influence of environmental factors have hampered identification of the genetic factors which are involved in episodic diseases such as migraine, episodic ataxia and epilepsy. The study of rare, but clearly genetically determined subtypes, may help to unravel the pathogenesis of the more common forms. Recently, different types of mutation in the brain-specific $P / Q$ type calcium channel $\alpha_{1 A}$ subunit gene (CACNA1A) on chromosome 19p13 were shown to be involved in three human disorders: familial hemiplegic migraine (FHM), episodic ataxia type 2 (EA2), and chronic spinocerebellar ataxia type 6 (SCA6). In addition, evidence is accumulating that the same gene is also involved in the common forms of migraine with and without aura. In the tottering and leaner mouse, which are characterised by epilepsy and ataxia, similar mutations were identified in the mouse homologue of the calcium channel $\alpha_{1 \mathrm{~A}}$ subunit gene. These findings add to the growing list of episodic (and now also chronic) neurological disorders, which are caused by inherited abnormalities of voltage-dependent ion channels. The findings in migraine illustrate that rare, but monogenic variants of a disorder, may be successfully used to identify candidate genes for the more common, but genetically more complex, forms.
\end{abstract}

Keywords: migraine; familial hemiplegic migraine (FHM); episodic ataxia type 2 (EA2); spinocerebellar ataxia type 6 (SCA6); CADASIL; epilepsy; CACNA1A; P/Q type calcium channel

\section{Gene Mapping Approaches to Multifactorial Disorders}

The search for genetic risk factors for multifactorial diseases is complex. This is particularly true of episodic

Correspondence: MD Ferrari, Department of Neurology, L eiden U niversity Medical Centre, PO Box 9600, 2300 R C L eiden, The Netherlands. Tel: (0)71 5262134; Fax: (0)71 5248253; E-mail: mferrari@neurology.azl.nl.

* A full list of all members, see ref 17.

R eceived 280 ctober 97; revised 3 February 98; accepted 20 February 98 disorders. When family material is abundant and candidate genes are scarce, random genome screening for linkage is the method of choice, although there are clear views on the optimal statistical approach. ${ }^{1-4}$ L inkage findings, after independent confirmation, may point to positional candidate genes as opposed to functional candidates based on pathophysiological hypotheses.

A third approach is to localise genes which cause rare M endelian variants of a specific multifactorial disorder. 
These phenotypic candidate genes can then be evaluated as possible susceptibility loci, under the assumption that mutations which convey susceptibility to a complex disease are allelic to more serious gene defects leading to Mendelian segregation. Since the rare variants usually have a clear inheritance pattern, candidate loci can be identified by using regular lod score analyses. This approach has proved to be successful in the search for genes implicated in migraine.

\section{Migraine, a Multifactorial Disorder}

$M$ igraine is an episodic neurological disorder, affecting up to $12 \%$ of males and $24 \%$ of females in the general population. ${ }^{5}$ Two main types are distinguished

(i) migraine without aura, typically characterised by attacks of severe unilateral pulsating headache, nausea, vomiting, and photo- and phonophobia, and

(ii) migraine with aura, in which the headache attacks are preceded by transient focal neurological, usually visual, aura symptoms.

The visual symptoms may include scintillating scotoma, blurred vision, flickering, dark spots. Both types of migraine attacks may coexist in the same patient but usually one type prevails. A ttacks of migraine without aura are found in $67 \%$ of patients and attacks of migraine with aura in $33 \% .{ }^{6} \mathrm{M}$ igraine frequently runs in families, but family and segregation studies have produced conflicting results with respect to the mode of inheritance. ${ }^{7-10}$ From a large proband-oriented clinical study ${ }^{6}$ it was inferred that migraine with aura is largely or exclusively determined by genetic factors, whereas migraine without aura seems to be caused by a combination of both genetic and environmental factors. Thus migraine is a multifactorial disorder.

\section{Familial Hemiplegic Migraine}

\section{Clinical Features and Linkage Data}

Familial hemiplegic migraine (FHM) is a rare autosomal dominantly inherited subtype of migraine with aura. ${ }^{11}$ Patients with FHM have attacks of migraine with aura which are also associated with hemiparesis or hemiplegia (one-sided weakness of the body). Otherwise symptoms of headache and aura phase are similar to those of 'non-hemiplegic' migraine with aura, but may be much longer. In addition, some FHM families are associated with progressive permanent ataxia (disturbance of coordination of movements). Patients with FHM may also have attacks of 'non-hemiplegic' migraine and in families with $\mathrm{FHM}$, both individuals with FHM and individuals with 'non-hemiplegic' migraine are to be found. These observations strongly suggest that $\mathrm{FH} \mathrm{M}$ is part of the migraine spectrum, and that genes involved in FHM are candidate genes for 'non-hemiplegic' migraine with and without aura.

In approximately $50 \%$ of the reported families, FH M has been assigned to chromosome $19 \mathrm{p} 13 .{ }^{12,13}$ R ecently two groups also found linkage to chromosome $1 .{ }^{14,15} \mathrm{~A} \mathrm{n}$ A merican group showed, in one large family, a lod score of 3.04 at $\Theta=0.09$ with marker D 1S249 on chromosome $1 q 31,{ }^{15}$ whereas a French group showed linkage to chromosome 1q21-q23 in three FH M families. ${ }^{14}$ Further analysis has yet to disclose whether chromosome $1 \mathrm{q}$ harbours one or two FHM genes. There remain some FH M families unlinked to chromosome 19 or chromosome 1, indicating at least a third gene involved. ${ }^{14}$

So far very few clinical differences between the FH M families linked to chromosome 19 and the nonchromosome 19 linked families have been found except for cerebellar ataxia that appears in approximately $50 \%$ of the chromosome 19 linked but in none of the unlinked FHM families. ${ }^{12,13,16-20}$ Presumably, FH M and cerebellar degeneration reflect defects in the same gene in chromosome 19 linked FHM families. ${ }^{10,20}$ In addition, patients from families linked to chromosome 19 are more likely to have attacks triggered by minor head trauma or attacks associated with coma in comparison with patients from families not linked to this chromosome. ${ }^{18}$

\section{FHM: a Channelopathy}

\section{Molecular Biology of Calcium Channels}

Six functional subclasses of calcium channels have so far been defined by electrophysiological and pharmacological criteria. The classes fall into two major categories: low-voltage activated ( $T$ type) and high-voltage activated channels ( $L, N, P, Q, R$ type) ${ }^{21-24}$ Calcium channels are multiple-subunit complexes composed of a major transmembrane $\alpha_{1}$ unit and smaller auxiliary polypeptides which include a $\beta$ subunit and the disulphide-linked $\alpha_{2} \delta$ subunit. In skeletal muscle a $\gamma$ subunit may also form part of the channel complex. The $\alpha_{1}$ subunit is the most important component and acts as 
a voltage sensor and forms the ion-conducting pore modified by the other subunits. ${ }^{25}$

Six genes (A, B, C, D, E and S) have been identified that encode $\alpha_{1}$ subunits (see Table 1). ${ }^{22-24,26}$ The $\alpha_{1}$ subunit topology is very similar to the structure seen in voltage-dependent $\mathrm{Na}^{+}$and $\mathrm{K}^{+}$channels. ${ }^{22}$ The $\alpha_{1}$ subunit consists of four internal homologous repeats (I-IV), each containing six putative $\alpha$-helical membrane spanning segments (S1-S6) and one poreforming $(P)$ segment between $S 5$ and $S 6$ that spans only the outer part of the transmembrane region. ${ }^{27}$ The $\mathrm{S} 4$ segment contains a positively charged amino acid in every third or fourth position and is the voltage sensor for the voltage-gated ion channels. ${ }^{23}$

The $\beta$ subunits are cytoplasmic proteins capable of modulating current amplitude, activation and inactivation kinetics, and voltage dependence when coexpressed with $\alpha_{1}$ subunits. ${ }^{28} \beta$ subunits are encoded by four different genes, all expressed in brain (Table 1 ).

The $\alpha_{2} \delta$ subunit is encoded by a single gene (Table 1 ) and consists of glycosylated $\alpha_{2}$ and $\delta$ proteins linked together by disulphide bonds with $\delta$ as the transmembrane protein anchor and $\alpha_{2}$ extracellular.

A dditional molecular diversity arises from alternative splicing of the $\alpha, \beta$ and $\alpha_{2} \delta$ transcripts. ${ }^{24,28}$ The characteristics of the different calcium channel types are primarily correlated with the different $\alpha_{1}$ isoforms. ${ }^{29}$ The $\alpha_{1 \mathrm{~A}}$ subunit encodes $\mathrm{P}$ and $\mathrm{Q}$ type calcium channels which were originally identified in cerebellar Purkinje cells ${ }^{30}$ and granule cells. ${ }^{31} \mathrm{P}$ and $\mathrm{Q}$ type calcium channels differ in inactivation kinetics possibly due to $\alpha_{1 \mathrm{~A}}$ subunit splice variants, ${ }^{32}$ post-translational modification, or the influence of an auxiliary subunit. ${ }^{33}$

\section{Mutations in the P/Q Type Calcium Channel $\alpha_{1 A}$ Subunit Gene in FHM}

U sing exon trapping, a human CDNA highly homologous to a brain-specific rabbit and rat voltage gated $P / Q$ type calcium channel $\alpha_{1 A}$ subunit gene was identified. ${ }^{34-36}$ The human gene was designated CACNLIA $4{ }^{37}$ but according to a newly proposed nomenclature the gene is called CACNA $1 A .{ }^{29}$ The gene is transcribed specifically in cerebellum, cerebral cortex, thalamus and hypothalamus.

Four different missense mutations in five unrelated FHM families have been identified (see Figure 1 ). ${ }^{36} \mathrm{~A}$ transition from $G$ to $A$ was identified resulting in an arginine to glutamine substitution (R 192Q) within the fourth segment of the first membrane spanning domain (IS4). The highly conserved S4 segment is thought to be part of the voltage sensor. The second mutation

Table 1 Calcium channel subunits

\begin{tabular}{|c|c|c|c|c|c|c|c|}
\hline Subunit & Nomenclature & $\begin{array}{l}\text { Channel } \\
\text { type }\end{array}$ & $\begin{array}{l}\text { Pharmacology } \\
\text { (blockers) }\end{array}$ & L ocation & Distribution & $\begin{array}{l}\text { Human } \\
\text { disorders }\end{array}$ & $\begin{array}{l}\text { Mouse } \\
\text { models }\end{array}$ \\
\hline$\alpha 1 \mathrm{~A}$ & CACNA 1 A & $\mathrm{P} / \mathrm{Q}$ & $\begin{array}{l}\omega \text {-A gatoxin IVA } \\
\omega \text {-Conotoxin M V IIC }\end{array}$ & $19 p 13$ & neuronal, endocrine & FHM , EA 2, SCA 6 & $\begin{array}{l}\text { Tottering }(\mathrm{tg}) \\
\text { L eaner }(\mathrm{tg})\end{array}$ \\
\hline$\alpha 1 B$ & CACNA 1B & $\mathrm{N}$ & $\begin{array}{l}\omega \text {-Conotoxin G VIA } \\
\omega \text {-Conotoxin M VIIA }\end{array}$ & $9 q 34$ & neuronal & & \\
\hline$\alpha 1 C$ & CACNA $1 \mathrm{C}$ & L & Dihydropyridines & $12 \mathrm{p} 14.3$ & $\begin{array}{l}\text { cardiac and smooth } \\
\text { muscle, neuronal }\end{array}$ & & \\
\hline$\alpha 1 D$ & CACNA 1D & $L^{-1}$ & Dihydropyridines & $3 p 14.3$ & neuronal, endocrine & & \\
\hline$\alpha 1 \mathrm{E}$ & CACNATE & $\mathrm{R} / \mathrm{T}$ & & $1 q 25-q 31$ & neuronal & & \\
\hline$\alpha 1 S$ & CACNA IS & L & Dihydropyridines & $1 q 31-q 32$ & skeletal muscle & H уроК K, M H S2 & \\
\hline $\begin{array}{l}\beta 1 \\
\beta 2 \\
\beta 3\end{array}$ & $\begin{array}{l}\text { CACNB } 1 \\
\text { CACNB2 } \\
\text { CACNB3 }\end{array}$ & & & $\begin{array}{l}17 q 11.2-q 22 \\
10 p 12 \\
12 q 13\end{array}$ & $\begin{array}{l}\text { skeletal muscle, neuronal } \\
\text { heart, aorta, neuronal } \\
\text { neuronal, aorta, trachea, } \\
\text { lung, heart, skeletal } \\
\text { muscle }\end{array}$ & & \\
\hline$\beta 4$ & CACNB 4 & & & $2 q 22-q 23$ & neuronal & & L ethargic (Ih) \\
\hline$\alpha 2 \delta$ & CACNA-2 & & & $7 q 21-q 22$ & $\begin{array}{l}\text { skeletal muscle, heart, } \\
\text { vascular and intestinal } \\
\text { smooth muscle, neuronal }\end{array}$ & & \\
\hline$\gamma$ & CACNG & & & $17 q 24$ & skeletal muscle & & \\
\hline
\end{tabular}

FHM =Familial Hemiplegic Migraine; EA 2=Episodic A taxia type 2; SCA 6=SpinoCerebellar A taxia type 6; HypoK K= $\mathrm{H}$ ypokalemic Periodic Paralysis; M H S2 =M alignant $\mathrm{H}$ yperthermia susceptibility2; see R ef N os 110, 111. 
located between each S5 and S6, are involved in the

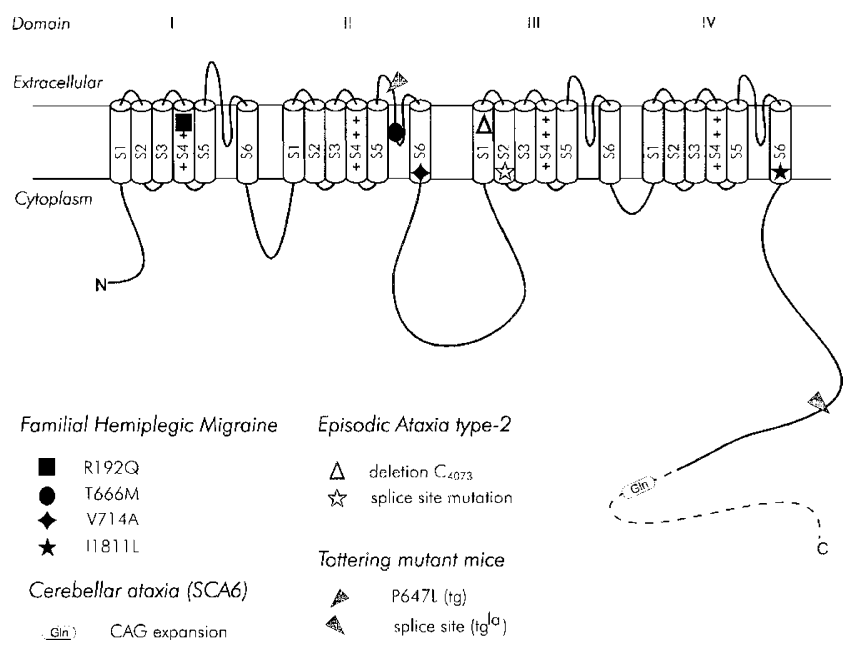

Figure 1 M embrane topology of $\alpha_{1 \mathrm{~A}}$ subunit of the $\mathrm{P} / \mathrm{Q}$ type $\mathrm{Ca}^{++}$channel, CACNA1A. The $\alpha_{1 \mathrm{~A}}$ subunit consists of four internal homologous repeats (I-IV), each containing six putative $\alpha$-helical membrane spanning segments S1-S6 and one pore-forming (P) segment between S5 and S6 that spans only the outer part of the transmembrane region. The S4 segment contains a positively charged amino acid in every third or fourth position and is the voltage sensor for the voltagegated ion channels. The location and amino acid substitutions are indicated for mutations that cause familial hemiplegic migraine $(\mathrm{FHM})$, episodic ataxia type 2 (EA2), tottering mouse $(\operatorname{tg})$, leaner mouse ( $\operatorname{tg}^{\mathrm{la}}$, and spinocerebellar ataxia type 6 (SCA 6).

occurred within the pore-forming $(P)$ hairpin loop of the second domain replacing a threonine residue for methionine $(\mathrm{T} 666 \mathrm{M})$. These conserved $P$ segments, ion-selectivity of ion channels and present binding sited for toxins. ${ }^{27}$ Two other mutations were located in the sixth transmembrane spanning segment of repeats II and IV. The IIS6 mutation was a T-to-C transition at codon 714, resulting in a valine-to-alanine substitution (V 714A ). The IV S6 mutation was an A -to-C transversion at codon 1811 that resulted in substitution of isoleucine for leucine (I1811L) and was found in two independent FHM families. The S6 mutations do not actually change the neutral-polar nature of the amino acid residues, but the original residues are conserved in all calcium channel $\alpha_{1}$ subunit genes described. ${ }^{26}$ R esidues in the $S 6$ transmembrane segments may be of influence in the inactivation of the calcium channel. ${ }^{38}$ The missense mutations in FHM suggest a molecular mechanism similar to what is found in other human channelopathies. B oth alleles are likely to be expressed with the allele harbouring the missense mutation resulting in gain-of-function variants of the $P / Q$ type calcium channels. Such mutations have been described in the $\alpha$ subunit of the skeletal muscle sodium channel resulting in hyperkalemic periodic paralysis, paramyotonia congenita, and the sodium channel myotonias (Table 2). . $^{39,40}$

Interestingly, the second FH M locus on chromosome lq is located near a brain-specific $R / T$ calcium channel $\alpha_{1 E}$ subunit gene (CACNA IE). M utation analysis has yet to disclose whether this CACNA IE gene is involved in chromosome 1-linked FHM families.

Table 2 Heritable neurological disorders of ion channels

\begin{tabular}{|c|c|c|}
\hline Disorder & Ion channel gene & Chromosomal location \\
\hline H yperkalemic periodic paralysis & SCNA 4 (skeletal muscle sodium channel) & $17 q 23-25$ \\
\hline Paramyotonia congenita & " & , \\
\hline $\begin{array}{l}\text { Pure myotonias (fluctuans, permanens, } \\
\text { acetazolamide-responsive) }\end{array}$ & $"$ & " \\
\hline $\begin{array}{l}\text { H ypokalemic periodic paralysis } \\
\text { M alignant hyperthermia susceptibility2 }\end{array}$ & CACNA IS (skeletal muscle calcium channel) & $1 q 31-32$ \\
\hline Familial hemiplegic migraine & CACNA 1A (neuronal calcium channel) & $19 p 13$ \\
\hline $\begin{array}{l}\text { E pisodic ataxia2 } \\
\text { Spinocerebellar ataxia6 }\end{array}$ & " & " \\
\hline E pisodic ataxial & KCNA 1 (neuronal potassium channel) & 12p14 \\
\hline M alignant hyperthermia susceptibility 1 & RY R I (ryanodine calcium channel) & $19 p 13.1$ \\
\hline $\begin{array}{l}\text { A utosomal dominant nocturnal } \\
\text { frontal lobe epilepsy }\end{array}$ & $\begin{array}{l}\text { CHRNA } 4 \text { (neuronal nicotinic acetylcholine } \\
\text { receptor) }\end{array}$ & $20 q 13.2-q 13.3$ \\
\hline H yperekplexia & GLRA 1 (neuronal glycine receptor) & $5 q 33-35$ \\
\hline Thomsen's myotonia congenita & CL CN 1 (skeletal muscle chloride channel) & $7 q 35$ \\
\hline B ecker's myotonia congenita & " & " \\
\hline M yotonia levior & " & ," \\
\hline
\end{tabular}

A Il disorders have an autosomal dominant inheritance except for Becker's myotonia congenita which has autosomal recessive inheritance $26,112,113$. 


\section{Involvement of the $P / Q$ type Calcium Channel Gene on Chromosome 19 in 'non-Hemiplegic' Migraine}

Previously, tentative evidence that the FHM locus on chromosome 19p13 is involved in 'non-hemiplegic' migraine with and without aura has been found. ${ }^{41}$ However, the results were inconclusive as to the magnitude of the involvement and the relative importance of migraine with aura and migraine without aura. A second affected sib pair analysis was performed in an independent additional sample of 36 extended Dutch families, with migraine with aura and migraine without aura. ${ }^{42}$ Significant increased sharing of the marker alleles in sibs with migraine with aura (maximum multipoint lod score (MLS) was 1.29 corresponding with $\mathrm{P}=0.013$ approximately) was confirmed. No such increased sharing was found for migraine without aura. A combined analysis for both migraine types, including sib pairs in which one had migraine with aura and the other migraine without aura, resulted in an even more significant increased sharing ( $M L S=1.69$ corresponding approximately with $P=0.005)$. The relative risk ratio for a sib $\left(\lambda_{s}\right)$ to suffer from migraine with aura, defined as the increase in risk of the trait attributable to the $19 q 13$ locus, was $\lambda_{s}=2.4$. When combining migraine with and without aura, $\lambda_{s}$ was 1.25 . When the results obtained in the study including $D$ utch families and those obtained in our previous study, mainly including German families, ${ }^{41}$ were combined with maximum multipoint lod score raised to 2.27 ( $P=0.001$ approximately). These two studies provide independent evidence of the involvement of the region on chromosome $19 q 13$ containing the $P / Q$ type calcium channel $\alpha_{1 \mathrm{~A}}$ subunit gene in the etiology of migraine; the contribution to migraine with aura, however, seems stronger. Mutation analysis in patients with migraine has yet to reveal when the known FHM mutations contribute to the etiology of migraine or other specific variants of this gene are involved in migraine with and without aura.

\section{Role of Calcium Channels in the Pathophysiology of Migraine}

Physiologically, calcium acts as an intracellular second messenger by initiating or regulating numerous bio- chemical and electrical events in the cell. Calcium ions are implicated in the regulation of several enzymes and for the control of the activity of several other ion channels. ${ }^{43}$ They also control many neuronal events such as neurotransmitter release, ${ }^{25,44-47}$ synaptogenesis, and neurite outgrowth. ${ }^{43} \mathrm{P} / \mathrm{Q}$ type calcium channels seem to be more effective at modulating neurotransmitter release than other channel types. ${ }^{48}$

Most current models of migraine suggest that serotonin (5-hydroxytryptamine, 5-HT) has a central role in migraine pathophysiology. ${ }^{49} \mathrm{E}$ ffective specific acute anti-migraine drugs all share the ability to stimulate neuronal and vascular $5-\mathrm{HT}_{1}$ receptors, thereby (among other effects) inhibiting release of vasoactive neuropeptides. ${ }^{50,51}$ Remarkably, $\mathrm{P}$ type neuronal $\mathrm{Ca}^{2+}$ channels mediate neurotransmitter release including $5-\mathrm{HT}^{52,53}$ Conversely, serotonin acts at $5-\mathrm{HT}_{2 \mathrm{c}}$ receptors to increase intracellular calcium activity in choroid plexus epithelial cells, both by liberating $\mathrm{Ca}^{2+}$ from intracellular stores and by activating a $\mathrm{Ca}^{2+}$ influx pathway. ${ }^{54}$ In rat motorneurones serotonin inhibits $\mathrm{N}$ and $\mathrm{P}$ type calcium currents. ${ }^{55}$

In the pathophysiology of migraine, cortical spreading depression may initiate migraine attacks. ${ }^{56} \mathrm{Calcium}$ and other ion channels are important in the mechanism of cortical spreading depression. ${ }^{56,57}$ Therefore impaired function of cerebral calcium channels may facilitate initiation of attacks.

There is also evidence of involvement of $\mathrm{M} \mathrm{g}^{2+}$ in the pathophysiology of migraine. M agnetic resonance spectroscopy studies suggest that intracellular brain magnesium is reduced in migraine patients and that the regional distribution of brain magnesium is altered in patients with $\mathrm{FHM}{ }^{58,59}$ Preliminary clinical trial data suggest that chronic administration of magnesium may reduce migraine attack frequency. ${ }^{60}$ Interestingly, $\mathrm{M} \mathrm{g}^{2+}$ is known to interfere with $\mathrm{Ca}^{2+}$ channels. $^{61,62}$

Hormones seem to be of importance in migraine because there is a female preponderance among migraine patients, and in females attacks may be affected by menstruation and pregnancy. A $n$ influence of hormones on ion channels has been considered in hypokalemic and hyperkalemic periodic paralysis. ${ }^{63,64}$ Joëls and $\mathrm{K}$ arst ${ }^{65}$ investigated the effects of oestradiol and progesterone on voltage-gated calcium and potassium conductances in rat $\mathrm{C}_{\mathrm{A} 1}$ hippocampal neurons and concluded that long-term modulation with these hormone levels alters the calcium but not the potassium currents. 


\section{Episodic Ataxia Type 2}

\section{Clinical Features and Linkage Data}

Episodic ataxia (EA) is characterised by recurrent attacks of generalised ataxia and other signs of cerebellar dysfunction. ${ }^{66}$ The disease is heterogeneous and at least two autosomal dominantly inherited types are distinguished. E pisodic ataxia type 1 (EA 1) is characterised by brief episodes of ataxia and dysarthria (disturbed articulation) lasting seconds to minutes and is associated with interictal myokymia (twitching of small muscles). ${ }^{66} \mathrm{EA} 1$ is caused by missense mutations in a potassium channel gene (KCNA 1) on chromosome 12 p14. ${ }^{67}$ E pisodic ataxia type 2 (EA 2) is also called acetazolamide responsive paroxysmal cerebellar ataxia (APCA), paroxysmal vestibulocerebellar ataxia (PVCA), or hereditary paroxysmal cerebellar ataxia (H PCA ) ${ }^{68-71}$ EA 2 is characterised by attacks of generalised ataxia, usually associated with an interictal nystagmus (eye movement disturbance). Treatment with acetazolamide is very effective in preventing attacks. A ttacks typically last a few hours and can be precipitated by emotional stress, exercise, or alcohol. Clinical onset generally occurs in childhood or early adulthood. ${ }^{66}$

E pisodic ataxia 2 was linked to the same interval on chromosome $19 \mathrm{p}$ as $\mathrm{FHM}{ }^{68-71}$ Notwithstanding the clinical differences between EA 2 and FHM there are also some similarities. Both are episodic disorders, patients with EA 2 may show migraine-like features, ${ }^{68,71-74}$ and in both disorders there may be progressive ataxia and dysarthria and cerebellar atrophy on magnetic resonance imaging. ${ }^{16,17,75}$

\section{Mutations in the P/Q Type Calcium Channel $\alpha_{1 A}$ Subunit Gene}

$B$ ecause of the clinical and genetic similarities between $\mathrm{FHM}$ and EA 2, families with EA 2 were included in the mutation analysis of the CACNA1A gene. Until now two different truncating mutations were identified in EA 2 families (see Figure 1 ). ${ }^{36}$ One mutation is a nucleotide deletion (deletion $\mathrm{C}_{4073}$ ) causing a frame shift and a premature stop. The other mutation affects the first invariant $\mathrm{G}$ nucleotide of the intron consensus sequence leading to aberrant splicing. Both mutations result in truncated $\alpha_{1 \mathrm{~A}}$ subunits which are unlikely to form functional calcium channels and may either degrade resulting in haploinsufficiency, or negatively influence channel assembly in the membrane.

\section{Spinocerebellar Ataxia6 and the P/Q Type Calcium Channel $\alpha_{1 A}$ Subunit Gene}

The autosomal dominant cerebellar ataxias (SCA) are a clinically and genetically heterogeneous group of disorders with many possible accompanying features in addition to the ataxia, such as ophthalmoplegia, pyramidal and extrapyramidal signs, neuropathy, dysarthria, amyotrophy, and pigmentary retinopathy. ${ }^{76} \mathrm{G}$ enes are located on chromosomes 6p22-p23 (SCA 1), ${ }^{77,78}$ 12q23-24.1 (SCA 2), ${ }^{79}$ 14q13.1 (SCA 3/M achado-J oseph disease, ${ }^{80,81}$ 16q24-ter (SCA 4), ${ }^{82} 11$ (SCA 5), ${ }^{83}$ and 3p12-p21.1 (SCA 7). ${ }^{84-86}$ For SCA 1, 2, 3, and 7 the disease-causing mutations have been identified as expanded and unstable CA G trinucleotide repeats. ${ }^{87-92}$ For SCA 4 and 5 the disease-causing genes are still to be identified.

Recently, six different CDNA isoforms of the CACN1A 1 gene have been reported of which three contained a 5-nucleotide insertion prior to the previously described stop codon, resulting in a shift of the open reading frame in which the CAG repeat is predicted to encode a polyglutamine stretch. ${ }^{36,93}$ Small triplet expansions of the intragenic CA G repeat ranging from 21 to 30 repeat units were observed in patients with autosomal dominant cerebellar ataxia (SCA 6), ${ }^{93-95}$ whereas normal chromosomes displayed 4-20 repeats. $^{36,93-96}$ The CA repeat length is inversely correlated with age at onset. ${ }^{94-96}$ A nticipation of the disease was observed clinically ${ }^{94}$ but no detectable intergenerational allele size change was seen in contrast to other disease-causing repeats (eg in other SCA $s$ and $H$ untington disease). The occurrence of the SCA 6 mutation was estimated to be $10 \%$ of SCA patients in G ermany, ${ }^{95}$ whereas in Japan SCA 6 comprised $30 \%$ of the examined ataxia patients and one homozygous case was found suggesting a founder effect. ${ }^{94}$

Interestingly, both chromosome 19 linked FHM families and EA 2 families may develop progresive cerebellar ataxia and atrophy. ${ }^{12,13,16-20,75}$ Screening for CA G repeat expansion in FHM and EA 2 families with chronic cerebellar ataxia has to be performed to answer the question whether the FHM and/or EA 2 mutations 
cause chronic progressive cerebellar ataxia independent of the number of CAG repeats.

\section{P/Q Type Calcium Channel $\alpha_{1 A}$ Subunit Gene in Mice with Epilepsy and Ataxia}

Simultaneously with the identification of mutations in $\mathrm{FHM}$ and EA 2, mutations in the CACNA $1 \mathrm{~A}$ gene were found in the tottering $(\mathrm{tg})$ and leaner mouse $\left(\mathrm{tg}^{\mathrm{la}}\right)$ phenotypes (Figure 1). ${ }^{97-98}$ These recessive tottering mice have been studied extensively as models for human epilepsy. ${ }^{100}$ The mutation in the tottering mouse is a missense mutation close to the pore-forming $\mathrm{P}$ loop of the second transmembrane domain, very similar to one of the FHM missense mutations, and most likely affects the pore function of the $P / Q$ type calcium channel. The more severe leaner mouse is associated with a splice site mutation producing an aberrant intracellular terminus and resembles the mutations found in two EA 2 families. Mutations at the mouse tottering locus result in intermittent convulsions similar to human absence epilepsy, motor seizures, and mild ataxia. The leaner $\left(\mathrm{tg}^{\mathrm{la}}\right)$ mouse suffers from absence seizures, but no motor seizures. The tg ${ }^{\text {la }}$ mutants are more ataxic and often do not survive past weaning. The profound chronic ataxia is associated with pervasive Purkinje- and granule cell loss throughout the anterior cerebellum and reduced cerebellar size. A third mouse strain, the rolling Nagoya ( $\mathrm{tg}^{\text {rol }}$ ) presents an intermediate phenotype; the ataxia is more severe than in the tg mouse, motor seizures do not occur, and they have a normal life span. ${ }^{97}$ No mutation for the $\operatorname{tg}^{\text {rol }}$ mouse has yet been identified.

It has been demonstrated that tottering mutant mice have a significantly increased threshold for cortical spreading depression [unpublished data], which is a phenomenon thought to be involved in the pathophysiology of migraine. In the tottering mouse a proliferation of noradrenaline axons arising from the locus coeruleus is considered to be one of the neuronal mechanisms underlying the generation of absence seizures. ${ }^{100}$ Interestingly, positron emission tomography studies in acute migraine attacks suggested the locus coeruleus and the dorsal raphe nucleus to be the 'migraine centre' in man. ${ }^{101}$ The tottering mice may therefore not only serve as a model for epilepsy and ataxia, but also for migraine.
Interestingly, it was recently shown that a mutation in the calcium channel $\beta 4$ subunit gene is associated with ataxia and seizures in the lethargic mouse (1h). ${ }^{102}$ Homozygotes of the 1 mouse are characterised by ataxia, lethargic behaviour, motor seizures and seizures resembling absence seizures of human petit mal epilepsy. ${ }^{102}$

\section{CADASIL: Clinical but no Genetic Overlap with Migraine}

Cerebral autosomal dominant arteriopathy with subcortical infarcts and leukoencephalopathy (CA DA SI L) is a rare disorder caused by mutations in a $\mathrm{N}$ otch 3 gene on chromosome $19 \mathrm{p}^{103,104}$ and characterised by recurrent subcortical ischaemic strokes, progressive vascular dementia, mood disorders with severe depression, ${ }^{105}$ and in $30 \%$ of patients by migraine with aura. ${ }^{105-107}$ O ne CA DA SIL family has been described with typical FHM attacks, ${ }^{108}$ and another family, linked to the CADASIL locus, with migraine and CADA SIL-like white matter lesions on magnetic resonance imaging. ${ }^{109}$ All these observations contributed to the clinical spectrum of migraine-FHM-CA DA SIL. Further study of this intriguing relation is needed.

\section{Discussion and Conclusions}

So far, different sets of mutations in the P/Q type calcium channel gene seem to be associated with specific clinical phenotypes although these phenotypes may show some clinical overlap. The mechanism in which these mutations produce both episodic and chronic disorders is not yet understood. Presumably, these mutations permit proper cell function until extraor intracellular conditions exacerbate the molecular pathology, leading to episodic failure of the channel function. In the long term, mutations may lead to impairment of inactivation of the calcium channel and a chronic disturbance of calcium homeostasis. The inability to restore the resting intracellular calcium levels may then induce a slow but progresive apoptotic neuronal cell death and a chronic progressive phenotype.

In summary, the identification of the P/Q type calcium channel in migraine, epilepsy, and ataxia is a leap forward in the understanding of neurological channelopathies. Furthermore, the identification of calcium channels involved in the pathophysiology of 
these disorders opens new avenues for the development of prophylactic treatment.

\section{Acknowledgements}

This work has been supported by the N etherlands O rganization for Scientific Research (NWO) (number 950-10-615, GMT) and the Phoenix Foundation (RAO).

\section{References}

1 Thomson $\mathrm{G}$ : I dentifying complex disease genes: progress and paradigms. Nat G enet 1994; 8: 108-110.

2 Lander $E, K$ ruglyak L: G enetic dissection of complex traits: guidelines for interpreting and reporting linkage results. Nat G enet 1995; 11: 241-247.

3 Greenberg DA, Hodge SE, V ieland VJ, Spence MA: $A$ ffecteds-only linkage methods are not a panacea. A $m$ J H um G enet 1996; 58: 892-895.

$4 \mathrm{~K}$ ruglyak $\mathrm{L}$ : N onparametric linkage tests are model free. A m J H um G enet 1997; 61: 251-255.

5 Russell MB, Rasmussen BK, Thorvaldsen P, Olesen J: Prevalence and sex-ratio of the subtypes of migraine. Int J E pidemiol 1995; 24: 612-618.

6 Russell MB, Olesen J: Increased familial risk and evidence of genetic factor in migraine. BMJ 1995; 311: 541-544.

7 R ussell MB, O lesen J: The genetics of migraine without aura and migraine with aura. Cephalalgia 1993; 13: 245-248.

8 M ochi M , Sangiorgi S, Cortelli P et al: Testing models for genetic determination in migraine. Cephalalgia 1993; 13: 389-394.

9 Stewart W F, Staffa J, L ipton R B, O ttman R : Familial risk of migraine: a population-based study. Ann Neurol 1997; 41: 166-172.

10 Haan J, Terwindt G M , Ferrari M D : G enetics of migraine: In: M athew NT (ed). Neurological Clinics. A dvances in H eadache. Saunders: Philadelphia, 1997, pp43-60.

$11 \mathrm{H}$ eadache Classification Committee of the International $\mathrm{H}$ eadache Society: Classification and diagnostic criteria for headache disorders, cranial neural gias and facial pain. Cephalalgia 1988; 8 (S7): 1-97.

12 Ophoff RA, van Eijk R, Sandkuijl LA et al: Genetic heterogeneity of familial hemiplegic migraine. $G$ enomics 1994; 22: 21-26.

13 Joutel $A$, D ucros A, Vahedi $K$ et al: G enetic heterogeneity of familial hemiplegic migraine. A $\mathrm{m} \mathrm{J} \mathrm{Hum} \mathrm{Genet}$ 1994; 55: 1166-1172.

14 Ducros A, Joutel A, Vahedi $K$ et al: Familial hemiplegic migraine: mapping of the second gene and evidence for a third locus. Cephalalgia 1997; 17: 232.

15 Gardner K, Barmada M, Ptacek LJ, H offman E P: A new locus for hemiplegic migraine is on chromosome $1 q 31$. N eurology 1997; 49: 1231-1238.

16 Joutel $A$, Bousser MG, Biousse $V$ et al: $A$ gene for familial hemiplegic migraine maps to chromosome 19. $\mathrm{N}$ at G enet 1993; 5: 40-45.
$17 \mathrm{H}$ aan J, Terwindt G M, B os PL, O phoff R A, Frants R R, Ferrari MD, for the $D$ utch M igraine Genetics R esearch $G$ roup: Familial hemiplegic migraine in The N etherlands. Clin Neurol Neurosurg 1994; 96: 244-249.

18 Terwindt GM, O phoff RA, H aan J, Frants R R, Ferrari $M D$, for the DMGRG: Familial hemiplegic migraine: a clinical comparison of families linked and unlinked to chromosome 19. Cephalalgia 1996; 16: 153-155.

19 Tournier-Lasserve E: Genetics of familial hemiplegic migraine: In: Sandler M, Ferrari M, Harnett S (eds). $M$ igraine. Pharmacology and $\mathrm{G}$ enetics. Chapman \& $\mathrm{H}$ all: L ondon, 1996, pp282-290.

20 Elliott MA, Peroutka SJ, Welch S, May EF: Familial hemiplegic migraine, nystagmus, and cerebellar atrophy. A nn Neurol 1996; 39: 100-106.

21 Catterall WA, Striessnig J: Receptor sites for $\mathrm{Ca} 2+$ channel antagnoists. Trends Pharmacol Sci 1992; 13: 256-262.

22 Catterall WA : Structure and function of voltage-gated ion channels. A nnu R ev B iochem 1995; 64: 493-531.

23 Varadi G, Mori Y, Mikala G, Schwartz A: Molecular determinants of $\mathrm{C}$ a2 + channel function and drug action. Trends Pharmacol Sci 1995; 16: 43-49.

24 Perez-R eyes E, Schneider T: Molecular biology of calcium channels. Kidney Int 1995; 48: 1111-1124.

25 Dunlap K, Luebke JI, Turner TJ: Exocytotic Ca2 + channels in mammalian central neurons. Trends N eurosci 1995; 18: 89-98.

26 Stea A, Soong TW, Snutch TP: Voltage-gated calcium channels: In: North RA (ed). Handbook of Receptors and Channels. Ligand- and Voltage-G ated I on Channels. CR C Press, 1995, pp113-153.

27 Guy HR, Durell SR: Three-dimensional models of ion channel proteins, 4th edn. In: Narahashi $\mathrm{T}$ (ed). Ion Channels Plenum Press: New York, 1996.

28 Schafer WR, K enyon CJ: A calcium-channel homologue required for adaptation to dopamine and serotonin in Caenorhabditis elegans. N ature 1995; 375: 73-78.

29 Lory P, O phoff RA, Nahmias J: Towards a unified nomenclature describing voltage-gated calcium channel genes. H um G enet 1997; 100: 149-150.

30 L linas R R, Sugimori M, Cherksey B : Voltage-dependent calcium conductances in mammalian neurons. The $P$ channel. A nn N Y A cad Sci 1989; 560: 103-111.

31 Zhang J $-F$, Randall AD, Ellinor PT et al: Distinctive pharmacology and kinetics of cloned neuronal $\mathrm{Ca} 2+$ channels and their possible counterparts in mammalian CNS neurons. Neuropharmacology 1993; 32: 1075-1088.

32 Snutch TP, Tomlinson WJ, Leonard JP, Gilbert M M: $D$ istinct calcium channels are generated by alternative splicing and are differentially expressed in the mammalian CNS. Neuron 1991; 7: 45-57.

33 Wheeler DB, Randall A, Sather WA, Tsien RW: Neuronal calcium channels encoded by the $\alpha 1 \mathrm{~A}$ subunit and their contribution to excitatory synaptic transmission in the CNS: In: Y u ACH, Eng LF, M CM ahan UJ, Schulman $H$, Shooter EM, Stadlin A (eds). Progress in Brain Research 105th edn Elsevier Science: A msterdam, 1995, pp65-78.

$34 \mathrm{M}$ ori $\mathrm{Y}$, Friedrich $\mathrm{T}, \mathrm{K}$ im M S et al: Primary structure and functional expression from complementary DNA of a brain calcium channel. Nature 1991; 350: 398-402. 
35 Starr TV, Prystay W, Snutch TP: Primary structure of a calcium channel that is highly expressed in the rat cerebellum. Proc Natl Acad Sci USA 1991; 88: 5621-5625.

36 O phoff RA, Terwindt G M, Vergouwe M N et al: Familial hemiplegic migraine and episodic ataxia type- 2 are caused by mutations in the $\mathrm{Ca}+$ channel gene CACNL 1A 4. Cell 1996; 87: 543-552.

37 Diriong S, Lory $P$, Williams M E, Ellis SB, H arpold M M, Taviaux S: Chromosomal localization of the human genes for $\alpha 1 \mathrm{~A}, \alpha 1 \mathrm{~B}$, and $\alpha 1 \mathrm{E}$ voltage-dependent $\mathrm{C} a 2+$ channel subunits. G enomics 1995; 30: 605-609.

38 Hering S, A czel S, Grabner $M$ et al: Transfer of high sensitivity for benzothiazepines from L-type to class $A$ (BI) calcium channels. J Biol Chem 1996; 271: 24471-24475.

39 Hudson A J, E bers G C, Bulman DE: The skeletal muscle sodium and chloride channel diseases. Brain 1995; 118: 547-563.

40 Cannon SC: Ion-channel defects and aberrant excitability in myotonia and periodic paralysis. Trends Neurosci 1996; 19: 3-10.

41 May A, Ophoff RA, Terwindt GM et al: Familial hemiplegic migraine locus on $19 p 13$ is involved in the common forms of migraine with and without aura. $\mathrm{H} \mathrm{um}$ G enet 1995; 96: 604-608.

42 Terwindt GM, Ophoff RA, Sandkuijl LA et al for the DMGRG: Involvement of the familial hemiplegic migraine gene on $19 \mathrm{p} 13$ in migraine with and without aura. Cephalalgia 1997; 17: 232.

43 Waard de M, G urnett CA, Campbell K P: Structural and functional diversity of voltage-activated calcium channels. In: Narahashi T (ed). Ionchannels Plenum Press: N ew York, 1996, pp41-87.

44 Volsen SG, D ay NC, M cC ormack A L et al: The expression of neuronal voltage-dependent calcium channels in human cerebellum. M ol Brain Res 1995; 34: 271-282.

45 Gaur S, Newcomb R, Rivnay B et al: Calcium channel antagonist peptides define several components of transmitter release in the hippocampus. Neuropharmacology 1994; 33: 1211-1219.

46 U chitel OD, Protti DA, Sanchez V, Cherksey BD, Sugimori $M$, L linàs R : P-type voltage-dependent calcium channel mediates presynaptic calcium influx and transmitter release in mammalian synapses. Proc Natl A cad Sci USA 1997; 89: 3330-3333.

$47 \mathrm{Wu} \mathrm{L}-\mathrm{G}$, Saggau P: Presynaptic inhibition of elicited neurotransmitter release. TINS 1997; 20: 204-212.

48 M intz I M, Sabatini B L, R egehr W G : Calcium control of transmitter release at a cerebellar synapse. N euron 1995; 15: 675-688.

49 Ferrari MD, Saxena PR: O n serotonin and migraine: a clinical and pharmacological review. Cephalalgia 1993; 13: 151-165.

50 M oskowitz M A : N eurogenic versus vascular mechanism of sumatriptan and ergot alkaloids in migraine. Trends Pharmacol Sci 1992; 13: 307-311.

51 Ferrari MD, Saxena PR: 5-HT1 receptors in migraine pathophysiology and treatment. Eur J Neurol 1995; 2: 5-21.
52 Codignola A, Tarroni P, Clementi $F$ et al: Calcium channel subtypes controlling serotonin release from human small cell lung carcinoma cell lines. J B iol Chem 1993; 268: 26240-26247.

53 Frittoli $E$, Gobbi $M$, M ennini T: Involvement of P-type $\mathrm{C}$ a2 + channels in the $\mathrm{K}+-$ and $\mathrm{d}$-Fenfluramine-induced [3H ]5-H T release from rat hyppocampal synaptosomes. Neuropharmacology 1994; 33: 833-835.

54 Watson JA, Elliott A C, Brown PD: Serotonin elevates intracellular $\mathrm{Ca} 2+$ in rat choroid plexus epithelial cells by acting on 5-HT2C receptors. Cell Calcium 1995; 17: 120-128.

55 B ayliss DA, U memiya $M$, Berger A J Inhibition of $\mathrm{N}$ and P-type calcium currents and the after-hyperpolarization in rat motoneurones by serotonin. J Physiol 1995; 485: 635-647.

56 Lauritzen $M$ : Pathophysiology of the migraine aura. The spreading depression theory. Brain 1994; 117: 199-210.

57 Shimazawa M , H ara H, Watano T, Sukamoto T: E ffects of $\mathrm{Ca} 2+$ channel blockers on cortical hypoperfusion and expression of c-Fos-like immunoreactivity after cortical spreading depression in rats. B J J Pharmacol 1995; 115: 1359-1368.

58 Welch KM A, B arkley G L, R amadan NM, D 'A ndrea G : NM R spectroscopic and magnetoencephalographic studies in migraine with aura: support for the spreading depression hypothesis. Path B iol 1992; 40: 349-353.

59 R amadan NM, B arker P, B oska MD, Norris L, B uuterworth E, Nelson J, Welch KMA: Selective occipital cortex magnesium $\mathrm{Mg} 2+$ deficiency reduction in familial hemiplegic migraine may reflect an ion channel disorder. Neurology 1996; A 168.

60 Peikert A, Wilimzig C, K öhne-Volland R: Prophylaxis of migraine with oral magnesium: results from a prospective, multi-center, placebo-controlled and doubleblind randomized study. Cephalalgia 1996; 16: 257-263.

61 A Itura BM: Calcium antagonist properties of magnesium: implications for antimigraine actions. M agnesium 1985; 4: 169-175.

62 Z hang A, Cheng PTO, A Itura B M : M agnesium regulates intracellular free ionized calcium concentration and cell geometry in vascular smooth muscle cell. Biophys A cta 1992; 1134: 25-29.

63 L ehmann-H orn F, R üdel R, R icker K: Non-dystrophic myotonias and periodic paralyses. Workshop report Neurosmuscul Disord 1993; 3: 161-168.

64 Lehmann-H orn F, Rudel R: M olecular pathophysiology of voltage-gated ion channels. Rev Physiol Biochem Pharmacol 1996; 128: 195-268.

65 J oëls M, Karst H: E ffects of estradiol and progesterone on voltage-gated calcium and potassium conductances in rat CA 1 hippocampal neurons. J Neurosci 1995; 15: 4289-4297.

66 Gancher ST, Nutt J G : A utosomal dominant episodic ataxia: a heterogeneous syndrome. M ov D isord 1986; 1: 239-253.

67 B rowne D L, G ancher ST, Nutt J G et al: E pisodic ataxia/ myokymia syndrome is associated with point mutations in the human potassium channel gene, KCNA 1 . Nat G enet 1994; 8: 136-140. 
68 von Brederlow, Hahn AF, Koopman WJ, Ebers GC, Bulman DE: Mapping the gene for acetazolamide responsive hereditary paroxysmal cerebellar ataxia to chromosome 19p. H um M ol G enet 1995; 4: 279-284.

$69 \mathrm{~K}$ ramer PL, Y ue Q, Gancher ST et al: A locus for the nystagmus-associated form of episodic ataxia maps to an $11-c M$ region on chromosome $19 p$. Am J Hum Genet 1995; 57: 182-185.

70 Teh BT, Silburn P, Lindblad $\mathrm{K}$ et al: Familial periodic cerebellar ataxia without myokymia maps to a 19-cM region on 19p13. Am J Hum Genet 1995; 56: 1443-1449.

71 Vahedi K, Joutel A, Bogaert van $P$ et al: A gene for hereditary paroxysmal cerebellar ataxia maps to chromosome 19p. Ann N eurol 1995; 37: 289-293.

72 Moon SL, Koller WC: Hereditary periodic ataxias: In: J ong de JMBV (ed). Handbook of Clinical Neurology. Hereditary Neuropathies and Spinocerebellar A taxias Elsevier Science: A msterdam, 1991, pp433-443.

73 Hawkes $\mathrm{CH}$ : Familial paroxysmal ataxia: report of a family. J Neurol Neurosurg Psychiatry 1992; 55: 212-213.

$74 \mathrm{~K}$ ramer PL, Smith E, Carrero-Valenzuela $\mathrm{R}$ et al: A gene for nystagmus-associated ataxia maps to chromosome 19p. A m J H um G enet 1994; 55: A 191.

75 Vighetto A, Froment J C, Trillet M, A imard G : M agnetic resonance imaging in familial paroxysmal ataxia. Arch Neurol 1988; 45: 547-549.

$76 \mathrm{H}$ arding AE: Clinical features and classification of inherited ataxias: In: $\mathrm{H}$ arding $\mathrm{EA}$, Deufel $\mathrm{T}$ (eds). Advances in Neurology. Raven Press: New York, 1993, $1-14$.

77 Yakura H, Wakisaka A, Fujimoto S, I takura K: Hereditary ataxia and H LA genotypes. N Engl J M ed 1974; 291: 154- 155

78 Banfi S, Chung MY, K wiatkowski TJ et al: M apping and cloning of the critical region for the spinocerebellar ataxia type 1 gene in a yeast artificial chromosome contig spanning 1.2 M b. G enomics 1993; 18: 627-635.

79 Gispert S, Twells R, O rozco G et al: Chromosomal assignment of the second (Cuban) locus for autosomal dominant cerebellar ataxia (SCA 2) to chromosome 12q23-24.1. N at G enet 1993; 4: 295-299.

80 Takiyama $\mathrm{Y}, \mathrm{N}$ ishizawa $\mathrm{M}$, Tanaka $\mathrm{H}$ et al: The gene for $M$ achado-Joseph disease maps to human chromosome 14q. N at G enet 1993; 4: 300-304.

81 Stevanin G, L e G uern E, R avise $N$ et al: A third locus for autosomal dominant cerebellar ataxia type I maps to chromosome 14q24.3-qter: evidence for the existence of a fourth locus. A m J H um G enet 1994; 54: 11-20.

82 Flanigan TP, Gardner $\mathrm{K}, \mathrm{A}$ Iderson $\mathrm{K}$ et al: A utosomal dominant spinocerebellar ataxia with sensory axonal neuropathy (SCA 4): clinical description and genetic localization to chromosome 16q22.1. A m J H um Genet 1996; 59: 392-399.

83 R anum LPW, Schut LJ, Lundgren JK, O rr HT, Livingston DM: Spinocerebellar ataxia type 5 in a family descended from the grandparents of President $L$ incoln maps to chromosome 11. N at G enet 1994; 8: 280-284.

84 Benomar A, Krols L, Stevanin G et al: The gene for autosomal dominant cerebellar ataxia with pigmentary macular dystrophy maps to chromosome 3p12-p21.1. N at G enet 1995; 10: 84-88.
85 Guow LG, Kaplan CD, Haines JH et al: Retinal degeneration characterizes a spinocerebellar ataxia mapping to chromosome 3p. N at G enet 1995; 10: 89-93.

86 Holmberg $M$, Johansson J, Forsgren L, Heijbel J, Sandgren $\mathrm{O}$, Holmgren $\mathrm{G}$ : Localization of autosomal dominant cerebellar ataxia associated with retinal degeneration and anticipation to chromosome 3p12-p21.1. H um Mol G enet 1995; 4: 1441-1445.

87 O rr HT, Chung MY, Banfi S et al: Expansion of an unstable trinucleotide CAG repeat in spinocerebellar ataxia type 1. N at $\mathrm{G}$ enet 1993; 4: 221-226.

88 Pulst SM, N echiporuk A, N echiporuk T et al: Moderate expansion of a normally biallelic trinucleotide repeat in spinocerebellar ataxia type 2. Nat Genet 1996; 14: 269-276.

89 Sanpei K, Takano H, I garashi S et al: I dentification of the spinocerebellar ataxia type 2 gene using a direct identification of repeat expansion and cloning technique, DIRE CT. Nat G enet 1996; 14: 277-284.

90 I mbert G, Sandou F, Y vert $G$ et al: Cloning of the gene for spinocerebellar ataxia 2 reveals a locus with high sensitivity to expanded CAG/glutamine repeats. Nat G enet 1996; 14: 285-291.

91 Kawaguchi $Y$, O kamoto T, Taniwaki $M$ et al: CAG expansions in a novel gene for $M$ achado-J oseph disease at chromosome 14q32.1. N at G enet 1996; 14: 221-227.

92 D avid G, A bbas N, Stevanin et al: Cloning of the SCA 7 gene reveals a highly unstable CAG repeat expansion. Nat G enet 1997; 17: 65-70.

93 Zhuchenko O, Bailey J, Bonnen $\mathrm{P}$ et al: A utosomal dominant cerebellar ataxia (SCA 6) associated with small polyglutamine expansions in the $\alpha 1 A$-voltage-dependent calcium channel. $\mathrm{N}$ at $\mathrm{G}$ enet 1997; 15: 62-69.

$94 \mathrm{M}$ atsuyama $\mathrm{Z}$, $\mathrm{K}$ awakami $\mathrm{H}, \mathrm{M}$ aruyama $\mathrm{H}$ et al: M olecular features of the CAG repeats of spinocerebellar ataxia 6 (SCA 6). Hum M ol G enet 1997; 6: 1283-1287.

95 Reiss 0 , Schöls $L$, Böttger $H$ et al: SCA 6 is caused by moderate CA G expansion in the $\alpha 1 A$-voltage-dependant calcium channel gene. Hum Mol Genet 1997; 6: 1289-1293.

96 I shikawa K, Tanaka H, Saito M et al: Japanese families with autosomal dominant pure cerebellar ataxia map to chromosome 19p13.1-p13.2 and are strongly associated with mild CA $\mathrm{G}$ expansions in the spinocerebellar ataxia type 6 gene in chromosome 19p13.1. A m J H um G enet 1997; 61: 336-346.

97 Fletcher CF, Lutz CM, O'Sullivan TN et al: A bsence epilepsy in tottering mutant mice is associated with calcium channel defects. Cell 1996; 87: 607-617.

98 Hess EJ: M igraines in mice? Cell 1996; 87: 1149-1151.

99 Doyle J, Ren XJ, Lennon G, Stubbs L: M utations in the CACNL 1A 4 calcium channel gene are associated with seizures, cerebellar degeneration, and ataxia in tottering and leaner mutant mice. Mamm Genome 1997; 8: $113-120$.

100 Kostopoulos GK : The tottering mouse: a critical review of its usefulness in the study of the neuronal mechanisms underlying epilepsy. J Neural Transm 1992; 35: 21-36.

101 Weiller C, May A, Limmroth $V$ et al: Brain stem activation in spontaneous human migraine attacks. $\mathrm{N}$ at M ed 1995; 1: 658-660. 
102 Burgess $\mathrm{DL}$, Jones JM, Meister $\mathrm{MH}$, Noebels JL: $M$ utation of the $\mathrm{Ca} 2+$ channel $\beta$ subunit gene $C$ chb4 is associated with ataxia and seizures in the lethargic (1h) mouse. Cell 1997; 88: 385-392.

103 Tournier-L asserve E, Joutel A, Melki J et al: Cerebral autosomal dominant arteriopathy with subcortical infarcts and leukoencephalopathy maps to chromosome 19q12. N at G enet 1993; 3: 256-259.

104 J outel A, Corpechot C, D ucros A et al: Notch3 mutations in CA DA SI L, a hereditary adult-onset condition causing stroke and dementia. Nature 1996; 383: 707-710.

105 Chabriat $\mathrm{H}$, Vahedi $\mathrm{K}$, Iba-Zizen MT et al: Clinical spectrum of CADA SIL: a study of 7 families. L ancet 1995; 346: 934-939.

106 Verin $M, R$ olland $Y, L$ andgraf $F$ et al: N ew phenotype of the cerebral autosomal dominant arteriopathy mapped to chromosome 19: migraine as the prominent clinical feature. J Neurol Neurosurg Psychiatry 1995; 59: 579-585.

107 Jung $\mathrm{HH}$, Bassetti $C$, Tournier-L asserve $E$, Vahedi $K$, A rnaboldi $M$, B latter A rifi $V$, B urgunder J - $M$ : Cerebral autosomal dominant aerteriopathy with subcortical infarcts and leukoencephalopathy: a clinicopathological and genetic study of a Swiss family. J N eurol Neurosurg Psychiatry 1995; 59: 138-143.
108 Hutchinson M, O'Riordan J, Javed M et al: Familial hemiplegic migraine and autosomal dominant arteriopathy with leukoencephalopathy (CA DA SIL). Ann Neurol 1995; 38: 817-824.

109 Chabriat H, Tournier-Lasserve $E$, Vahedi $K$ et al: A utosomal dominant migraine with MRI white-matter abnormalities mapping to the CA DA SIL locus. Neurology 1995; 45: 1086-1091.

110 R euter $\mathrm{H}$ : Diversity and function of presynaptic calcium channels in the brain. Curr Opin Neurobiol 1996; 6: 331-337.

111 Tsien W, Wheeler D B : Voltage-gated calcium channels: In: Carafoli E, K lee CB (eds). I ntracellular Calcium 1998, in press.

112 A ckerman MJ, Clapham DE : I on channels- basic science and clinical disease (review). N Engl J Med 1997; 336: 1575-1586.

113 Ptacek LJ: Channelopathies: ion channel disorders of muscle as a paradigm for paroxysmal disorders of the nervous system. Neuromuscul D isord 1997; 7: 250-255. 